THE

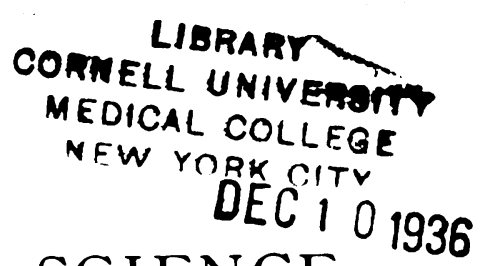

\title{
JOURNAL OF MENTAL SCIENCE
}

\author{
[Published by Authority of the Royal Medico-Psychological \\ Association.]
}

\begin{tabular}{lll}
\hline \hline No. $340\left[\begin{array}{c}\text { NEw SRRIs } \\
\text { No. } 304 .\end{array}\right]$ & SEPTEMBER, 1936. & Vol. LXXXII \\
\hline
\end{tabular}

\section{HAMILTON CLELLAND MARR.}

Scotrish Psychiatry has sustained a great loss through the passing of Dr. Hamilton C. Marr, Senior Medical Commissioner of the Scottish Board of Control.

Dr. Hamilton Marr only retired from office last October. He had made arrangements to take up his residence in the south of England, and was anticipating that rest from his official duties would allow him to devote time to scientific and literary writing, and maintain an active interest in all matters that pertained to the care and treatment of the insane. His sudden death, on June 3, I936, came as a great shock to his many friends and colleagues. He appeared to be in his usual health and was planting some violets in his garden when, without warning, he was seized with a sudden heart attack and passed away within a few minutes.

Dr. Marr was born in Govan in I870. He was the son of Mr. Hamilton Marr, who was well known in Glasgow and district both in his business capacity as the head of an important firm of sawmillers and as one who gave much of his time to public service in the Burgh and Parish of Govan where, for some years, he was an active member and chairman of the Parish Council and District Lunacy Board. Dr. Marr received his education in the High School, Glasgow, and from there proceeded to Glasgow University, where he graduated M.B., C.M., " with Distinction", and three years later received his M.D. " with Commendation". From the outset of his medical career Dr. Marr was attracted to the study of mental and nervous disorders. His first appointment was that of assistant to the late Dr. James Rutherford at the Crichton Royal Institution, Dumfries. Subsequently he was appointed Deputy Medical Superintendent of the Glasgow District Asylum, Woodilee, Lenzie, and in 
I90I, on the retirement of Dr. Robert Blair, he was appointed Medical Superintendent of that institution. Whilst occupying that position he was appointed Mackintosh Lecturer in Psychological Medicine in St. Mungo's Medical College, Glasgow, and Extra-Mural Lecturer in Mental Diseases in the University of Glasgow. Dr. Marr was an excellent teacher. He had the art of imparting knowledge in an interesting fashion. His lectures attracted many students, not a few of whom fell under his influence, and, like the writer, were privileged afterwards to look upon him as guide, counsellor and friend. In Igro, on the retirement of Dr. John Fraser, Dr. Marr was appointed H.M. Commissioner in Lunacy for Scotland, his senior colleague at that time being Sir John MacPherson. Later Dr. Marr became Senior Medical Commissioner of the General Board of Control.

During the Great War he served as Specialist in Mental Diseases to the Troops in Malta, and on returning to this country he was made Honorary Lieutenant-Colonel R.A.M.C. and Consultant in Neurology to the Scottish Command (I9I6-19I9). In 1927-I928 he was President of the Royal MedicoPsychological Association. In 1932 he received the C.B. In I934 the Royal Faculty of Physicians and Surgeons of Glasgow appointed him James Watson Memorial Lecturer, when he delivered two interesting addresses on "Madness in Literature and Life". Dr. Marr also acted as Medical Referee for Dumbartonshire in Mental and Nervous Affections occurring under the Workmen's Compensation Acts. His publications included Psychoses of the War, including Neurasthenia and Shell-shock, and various articles on insanity and mental deficiency in scientific journals and encyclopædias. He travelled extensively abroad, and was a keen student of French and Italian literature. Dante was one of his favourite authors, and "Dante and Rabelais" was the subject of his Presidential Address to the Association.

Of Dr. Marr it can truly be said that, both as Medical Superintendent and as Commissioner, his work was characterized by ceaseless energy and devotion to the interests, not only of the insane and mentally deficient, but also of the medical and nursing staffs in the various institutions throughout Scotland.

Dr. Marr's period of service as H.M. Commissioner-over twenty-five years - was longer than that of any of his predecessors. Throughout his whole career he was a keen searcher after truth. He may not always have seen eye to eye with his colleagues, but he was definite in his opinion and his work was characterized by obvious sincerity. Latterly he was keenly interested in the development of plans for the establishment of clinics for the treatment of early cases of mental disorder. He was intensely hopeful of seeing the practical fruition of his schemes. His passing is, indeed, a loss. 
Dr. Marr is survived by a widow, a son and a daughter. The interment, which took place at the Dean Cemetery, Edinburgh, on June 6, was attended by a large number of friends and colleagues.

Dr. Chambers of the Murray Royal said in his annual report: "It was a matter of severe regret not only to the officials and staff but to some of the older patients that this should be Dr. Marr's last visit as a Commissioner. $\mathrm{He}$ was invariably most courteous and considerate. Such opinions or criticisms as he offered were kindly and thoughtful, and showed his awareness, as a Physician-Superintendent of many years standing, of the variety of factors which attend and sometimes embarrass the administration of a busy mental hospital. His broad and liberal views and the feeling of support which he was able to give will be greatly missed." J. H. McD. 